\title{
Long and short-term effects of customisation on the service operations strategy
}

\section{Daniel Arias-Aranda*}

Universidad de Granada,

Departamento de Administración de Empresas y Marketing,

Facultad de Ciencias Económicas y Empresariales,

Campus de Cartuja s/n, 18071 Granada, Spain

Fax: 34-958-24-6222 E-mail: darias@ugr.es

*Corresponding author

\section{María J. Álvarez-Gil}

Universidad Carlos lil de Madrid,

Departamento de Economía de la Empresa,

C/Madrid, 126, 28903 Getafe, Madrid, Spain

Fax:34-91-6249708Ｅ-mail: catinaag@eco.uc3m.es

Abstract: This study has a twofold objective. First, we attempt to promote an understanding of the relationship between the design of Service Operations Strategies and their implementation, as they are driven by the customisation efforts. Second, we study the extent to which such service orientation may have two different forms, depending upon whether a company focuses on services that may have long-term or short-term effects on the customer nature. Consequently, a company aiming at raising its quality levels, and therefore its performance, should design and implement its Service Operations Strategy, mirroring the service orientation of the firm. We suggest four dimensions (Time, Space, Scale and Scope), which contribute towards explaining the two mentioned approaches. This may address the process of implementation of the Service Operations Strategy.

Keywords: service operations; operations strategy; new service development process; marketing/operations interface; service-positioning matrix; customisation; service quality.

Reference to this paper should be made as follows: Arias-Aranda, D., and Álvarez-Gil, M.J. (2004) 'Long and short-term effects of customisation on the service operations strategy', Int. J. Services Technology and Managemem, Vol. 5, No. 3, pp.233-246.

Biographical notes: Daniel Arias-Aranda is Full Professor of Operations Management at the University of Granada. He graduated in Economics and Business Administration at the University Carlos III of Madrid. He also worked as assistant professor at the Complutense University of Madrid where he achieved his doctoral degree in Business and Economics. He has published in International Journal of Service Industry Management, International Journal of Operations and Production Management, European Joumal of Imnovation Management and Industrial Maragement \& Data Systems, among others. His research interests focus on Service Process Development, Innovation in Services, Service Operations Strategy and Service Chain-Value Management 
among others. He coordinates and participates in several Postgraduate Intemational Programs with Universities in Chile and Slovakia among others.

Maria Álvarez-Gil is Full Professor of Operations Management at the University Carlos III de Madrid. She is member of POMS and EUROMA and has published in Journal of Operations Management, International Journal of Production Research, International Jounnal of Production Economics, Omega, Scandinavian Joumal of Management, and R\&D Management, among others. Her research interests focus on tourism and hospitality management, total environmental quality management, advanced manufacturing technologies, performance measurement systems. She coorganised the VIth Workshop on Quality Management in Services VI, and the 2nd International Research Workshop on Service Productivity, Madrid, April 15-19, 1996 (Universidad Carlos III de Madrid and EIASM).

\section{Introduction}

Nowadays, increasing competition as well as better and faster information availability due to new information technologies makes customer satisfaction the crucial issue for market positioning and differentiation in service industries. As a matter of fact, companies operating in the service sector that are keen on improving customer satisfaction should look for ways to assure that they are able to fulfill customer expectations. They are also supposed to find new approaches to their service delivery processes, so as to ensure that their operations gain superior reliability, consistency and replicability on a worldwide basis. Such an innovative process would imply a lasting impact on the firms' profitability and growth, as an increasing body of literature suggests [e.g. 1,2]: it has been found that there are strong positive relationships between customerrated levels of overall customer satisfaction and ROI, economic returns, and market value.

Customers have several expectations about different service experiences. They come into the service organisations with some expectation of what is likely to occur. Therefore, service firms are to determine which factors contribute the most to increase satisfaction by identifying the outstanding characteristics of a given service that customers are willing to find [3-5].

In world class organisations, customer satisfaction must permeate the entire service delivery process, from planning through execution [6]. Among the wide range of available options to increase satisfaction, customisation is considered to be the basic management tool. From the point of view of the Operations Management function, it can be described as the process of adapting products or services to customer preferences, by means of modifying or even restructuring the transformation system.

Service firms that offer customised services must be able to modify the patterns of its delivery operations systems as customer's expectation changes. This idea implies that customisation influences the design of the service delivery system, affecting both the content and the process of strategy formulation. Since the aggregated requirements imposed by the customisation focus could exceed the firm's resources or availability, it is important to evaluate and compare such requirements with the firm's available resources before adopting a customisation strategy. 
In this study, we have a twofold objective. First, we attempt to promote an understanding of the relationship between the design of Service Operations Strategies and their implementation, as they are driven by the customisation efforts. Thus, we are looking at those 'mantufacturing capabilities' of the Service firm, which result from implementing strategic plans aiming to answer customisation approaches.

The second problem to be addressed in this paper is related to the effort of classifying services by proposing an alternative framework to the Hayes and Wheelwright model. The relationship between volume and process stated by such model does not apply well in some service business [7] and it is also known that service firms are able to increase volume with no changes in the service process [8]. Other authors, such as Kellog and Nic [9] have also acknowledged the problem of combining volume and customisation on the service axis.

Several positioning matrix and frameworks have been suggested in order to fully understand the nature of service firms [7-14]. However, there is no general consensus regarding how and where to locate, rank, or classify service firms, as the models proposed use similar dimensions and variables either as different issues, or in a different vein (See [7] for a deep literature review).

In this paper, we suggest a new matrix which relies on a systematic procedure for customisation adoption and implementation. We assume that 'manufacturing capabilities' resulting from strategic investments are deployed in order to satisfy market requirements. It is at this point we suggest the LEC vs SEC matrix as a decision making tool for managers as well as academicians. This tool helps to evaluate whether planned efforts (following [15]) fit with the organisations' competitive priorities.

This article is organised as follows. We begin by reviewing customisation literature from the point of view of the operations management community. Then, we introduce our main contribution in this research work: the LEC-SEC matrix. Afterwards, we analyse the outstanding features in the design of a customisation-based strategy. Finally, we study the relationships between the customisation-based operations strategy and its positioning in the LEC-SEC matrix.

\section{Customisation and its time-based effects: the LEC-SEC matrix}

The management of the way a customer perceives a service experience is vital to the achievement of customer satisfaction with the service package. Customer satisfaction represents the difference between the customer's prior expectation of what he/she will like to obtain and what he/she actually perceives he/she has obtained [16]. It is the role of the marketing department to create an expectation of the service for customers, which should match the capability of the operations function to deliver the service in a way that meets the expectation. The process is not easy since each service experience has a unique nature and is essentially subjective [17].

The way customers perceive the value of a given service determines their degree of satisfaction, together with the design of the delivery process. There are at least three factors that, either by themselves, or by their joint action, may influence the perception process. The first factor is value perception, which is not static along time. Vandermerwe [18] points out a fundamental assumption of value from the customer's point of view. This assumption is based on the belief that value is not intrinsic to products or services, 
but what customers get out of them and that customers get this value over a period of time, rather than at a point of time'.

Secondly, customer satisfaction depends also on the kind of needs that are to be satisfied. In this context, Griffin and Hauser [19] suggest three types of needs: i) basic needs, i.e., what customers expect from the product, ii) articulated needs, meaning what the customers would like to see in the service, and iii) exciting needs, meaning those needs which will delight the customers if fulfilled.

A third factor affecting value perception is in regard to the difference between one's 'core' product offering and one's 'supplemental' (or sometimes 'value-added') services. In studies of customer satisfaction, managers are frequently surprised to find their customers judging them 'on the little things'. This is because customers take it for granted that the core offering will be of high quality. Thus, in an evaluation of a service experience, when choosing among different potential service providers, supplemental services provide greater information to customers and thus become features of the product offering that drive satisfaction and choice.

It is possible to influence these three factors through customisation. So, service operations strategy can be developed having as starting points the following parameters: time, kind of need to be satisfied and service nature (essential vs. complementary).

The Customisation efforts might be directed towards the achievement of Long-lasting Effects (we will refer to this trend as LEC) and/or Short-lasting Effects (referred as SEC). In the first case, the customer perceives customisation effects only in the first stages of the service delivery system. Then, customer service is standardised in the final stages. In the second case, the customer perceives customisation all the way through the service delivery stages. Therefore, the service is also considered as unique by the customer and suited to his/her wished or needs.

We define the Long-lasting Effects Customisation approach as 'those customisation efforts that provide solutions directly affecting and/or modifying the physical or psychical nature of customers for long periods of time in a far-reaching way'. Customers are aware of this direct influence of service on them. Those features of the service package that are most relevant for delivering these solutions are those more closely located to the core of the notion of service. Some services which are more differentiated in terms of personal relations [20] such as healthcare, professional services or education, constitute examples of LEC initiatives.

Short-lasting Effects Customisation (SEC) is the approach that shows a better fit when dealing with customers that demand services because of a sudden desire with a strong 'emotional' component. Hence, their behaviour obeys to impulsive wishes of getting things, experiences, sensations, etc. These impulses disappear as soon as the service encounter takes place, so that the effects of the service experience fade away very soon, i.e., we are speaking about 'exciting needs', according to Griffon and Hauser [19] terminology. Furthermore, customers are generally interested in all the ancillary elements that accompany the core of the service. For instance, some customers choose one theatre instead of another because of the screen size. These facts show that customer satisfaction not only depends on how well the core service is delivered, provided that it fulfils a minimum level (i.e., whenever the service conforms to its specifications), but on how well all the complementary offerings are delivered depending on environment conditions $[21,22]$. Restaurants, Entertainment Business, Travel Agencies, etc., are among those business wherein customisation activities can be led by their customers' wishes. 
The approaches LEC and SEC represent two extreme positions in a continuum; Service Firms, when choosing and developing their Operations Strategies, are expected to decide where they position themselves in such continuum, as shown by Figure 1. This is a strategic decision, since it will have much to do with the firm's competitive advantages [23]. Strategic assessment, including the external and internal analyses will assess service firms on how the service fits in the current mix of the company and how it will impact the firm's operations, by determining what skills, resources, and capabilities are needed in the development effort.

Figure 1 The LEC-SEC continuum

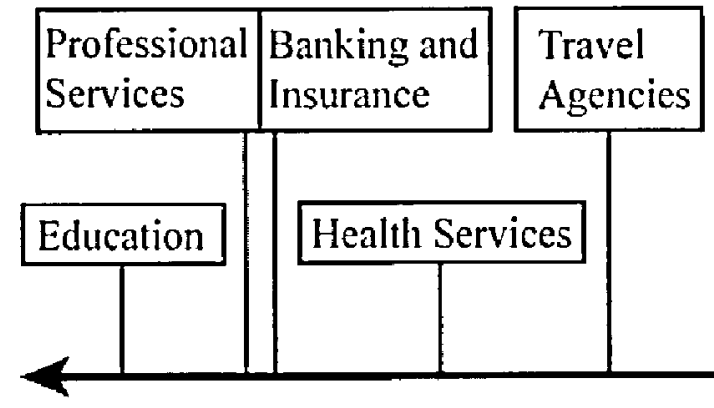

LEC

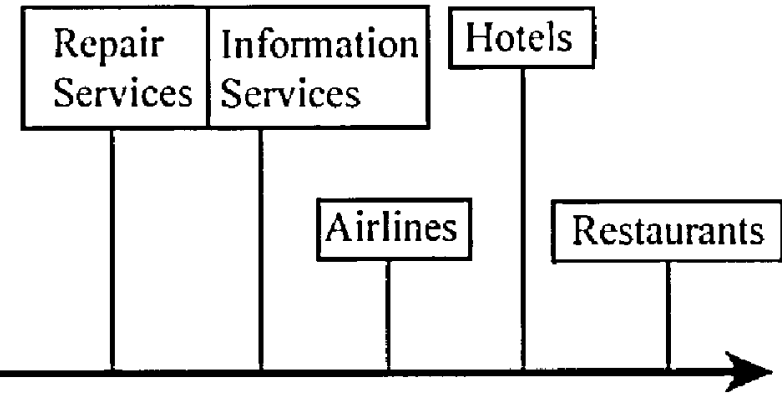

SEC

Firms might be allocated along this continuum, and they can shift positions. For example, we can consider most restaurants as SEC positioned, since most people visit them because of their desire to eat a determined kind of food sometime, not because eating there involves long lasting repercussion for the customer. We can also imagine a situation where a given restaurant has the policy of checking customers' health - by instantaneous blood analysis, for instance, before they can even make their orders. After the analysis, they offer the customer a menu that suits his/her health convenience. In this later case, the restaurant would be placing itself towards $L E C$. These characteristics would be taken into account along the design of the transformation processes, so that the required capabilities for delivering services that satisfy customers while contributing to the profitability of the companies are build on the company infrastructure. Consumers may wish for a wide variety of products and customisation to his or her needs, this flexibility and personalisation may not be financially affordable, however [6].

At this point, it is necessary to determine how the company should organise its 'production capabilities', mainly through back and front offices, so it enables it to achieve the required kind and level of customisation [24]. Hence, Designing the customer interface consists in systematically designing all interactions between customers and the service system so that consistency with the service concept is kept [25]. Each interaction has attributes determined by five dimensions [26]: purpose; duration and time delay; breadth and depth of options; nature of contact; and media employed. Some examples of such service Interaction purposes are Exchange of information, Delivery of intangible elements, Delivery of tangible elements, Tangibilisation or materialisation, Transaction, Problem solving, Sales Effort, Service recovery, Advertisement or awareness, Socialisation and Feedback.

Customisation implies flexibility and personnel empowerment for the Service Delivery System. Bateson [26] argues that customisation appears when the service 
encounter is dominated by the customer in the triad formed by Service Organisation, Contact Personnel and Customer. However, in standardised services too, customers have complete control over the limited service that is provided. In this context and for LEC service companies, the diagnosis process focuses on their customer long term expectations. In this process, customer remains as a passive receiver of the service. $\mathrm{He} / \mathrm{she}$ has little decision power as other professionals decide the type of service that he/she needs. He/she is checked in order to diagnose his/her needs, but he/she might not even be asked for opinions. One clear example of LEC diagnosis is emergencies health service at hospitals wherein injured individuals are given all necessary medical services as quick as possible without being asked for personal wishes. A similar example occurs with legal services, where the diagnosis process verifies customer's legal situation by different means, to solve his/her problem. He/she is not asked for his/her wishes, as the legal process does not depend on it.

The SEC diagnosis process, othervise, focuses on customer short-term wishes. In this case, his/her desires to know or enjoy a non-vital experience are a vital part of the diagnosis process. Customer involvement in the process is required, since he/she is expected to make expectations explicit, so that SEC service firms are able to adapt their service operations delivering system to every individual customer desires. For instance, an interior designer must know the customer's opinion in order to reach his/her satisfaction. Therefore, service delivery relies heavily in customer's wishes. SEC customers are even more interested in 'wrapping' elements of the service delivery system than in the core elements. It is in the auxiliary elements where the service organisations have an important differentiation opportunity because these elements are the key choice for SEC customers.

Besides, it should be taken into account that service encounters do not have the same temporal dimension, because of several factors, like the type of service, frequency at which the service is demanded, organisation of the service operations system to deliver the service, etc. Consequently, customisation initiatives can be classified accordingly. Second, some services are vital for customers, in the most literal sense of the term, thus meaning that the service encounter has to be organised according to the needs, and even urgency, of every customer. It also happens that customers require the delivery of services according to their sudden impulses and caprices. Obviously, not only different key elements would be required to fulfill these two types of customers expectations, but the consequences of deceiving customers can become indefinitely large as well. Therefore, customisation efforts can be classified according to the main reasons leading to customers' demands for service, and also depending on the effects of failure to meet customers' expectations. Why customers ask for a service not only conditions how the service has to be delivered but how long should its effects last. Hence, a second temporal dimension of customisation emerges: the one linked to the durability of the service, whether or not it succeeds in fulfilling customers' expectations.

\section{Customisation and service operations management}

When designing a service organisation, two basic dimensions are to be considered: Physical attributes such as the amount of service available and Policies and Practices to manage those physical attributes [27]. The main goal of the system design is to 
implement the service concept in a way that all components interact properly [25]. The design of the service delivery system will affect not only service perfonnance, but also, the firm's development capability and expertise. Once marketing and customer requirements are determined, they are combined with strategic priorities in order to redesign the new service. In this case, intangible resources play a central role to shape the service experience [25]. The firm's capabilities determine which approaches to the customisation-responsiveness squeeze may realistically take place [28]. Companies should reinforce their distinctive operating capabilities with the development of a tightly integrated system of supporting values, skills, technologies, supplier/customer relationships, human resources, and approaches to motivation that were neither easily copied nor transferable to other organisations. Every company has a unique combination of capabilities and market needs. This combination determines the firm's choice of tactics.

Thus, marketing has to identify, or create, the different markets and demands, while service operations focus should be based on the need to organise the firm's capabilities, so that those different requirements can be efficiently met. Then, it is possible that, under the umbrella of the customisation concept, companies address their customers to service experiences that are sold as unique and perceived as active contact experiences, but which have been delivered following a standardised process. As we will discuss later on this article, this can be the most likely case for SEC customisation.

The relationship between the Customisation concept and service operations management has appealed to several authors [3-5]. Since it means different types of interaction, it presents a range of challenging choices for the design and subsequent operation of the service business [29]. Among the firsts ones, Maister and Lovelock [30] used the concept of Customisation to classify service industries. Extent of Customisation and Customer Contact, - understood as the physical presence of the customer in the service system [31], are the two variables used for distinguishing among the service industries: Factory, Job Shop, Mass Service and Professional Service. Later, Schmenner [32] suggested a classification of service industries according to the Degree of Interaction and Customisation and the Degree of Labour Intensity. Schmenner's first dimension includes both Maister and Lovelock's dimensions and then, he weighs it against a cost structure ratio that he names Labour Intensity. Schmenner obtains four types of service industries labeled as: Service Factory, Service Shop, Mass Service and Professional Service.

At this point, we suggest a new integrative framework that draws from previous Schmenner [32] and Lovelock's [33] matrices. It is depicted by Figures 2a and 2b. The first one classifies service industries according to SEC, LEC and the Degree of Labour Intensity. We have four quadrants that delimit SEC and LEC Service Shop as well as SEC and LEC Professional Services. The first quadrant shows LEC Service Shop and all those services whose main activity mostly depends on the kind of assets that are included, that is to say, all those with a low degree of labour intensity. If we focus these low labour intensity Services towards SEC, we will obtain SEC Service Shops, which also depend on high assets investments but in this case wish-oriented. In the High Labour Intensity LEC services we find the classic Professional Services such as Physicians, Lawyers, Accountants or Architects, while the same costs structure with SEC gives us as result Travel Agencies and Fairs, Expositions or Conference Arranger services. Figure $2 b$ shows a similar classification with services directed at people or directed at things/businesses. 


\begin{tabular}{|c|c|c|c|c|c|}
\hline & LEC & SEC & & LEC & SEC \\
\hline $\begin{array}{l}\text { Low } \\
\text { Labour } \\
\text { Intensity }\end{array}$ & $\begin{array}{l}\text { LEC } \\
\text { Service Shop: } \\
\text { Hospitals, } \\
\text { Auto Repair. }\end{array}$ & $\begin{array}{l}\text { SEC } \\
\text { Service Shop: } \\
\text { Amusement } \\
\text { Parks }\end{array}$ & $\begin{array}{l}\text { People } \\
\text { Oriented }\end{array}$ & $\begin{array}{l}\text { People School } \\
\text { Health Care }\end{array}$ & $\begin{array}{l}\text { Passenger } \\
\text { Transportation } \\
\text { Beauty Salons }\end{array}$ \\
\hline $\begin{array}{l}\text { High } \\
\text { Labour } \\
\text { Intensity }\end{array}$ & $\begin{array}{l}\text { LEC } \\
\text { Professional } \\
\text { Services } \\
\text { Accountants }\end{array}$ & $\begin{array}{l}\text { SEC Professional } \\
\text { Services: } \\
\text { Travel Agencies }\end{array}$ & $\begin{array}{l}\text { Non- } \\
\text { People } \\
\text { Oriented }\end{array}$ & $\begin{array}{l}\text { Accounting } \\
\text { Legal Services } \\
\text { Freight } \\
\text { Transportation }\end{array}$ & $\begin{array}{l}\text { Pets Haircutting } \\
\text { Gardeners }\end{array}$ \\
\hline
\end{tabular}

Source: Adapted from Schmenner (1986)

In this case, we can distinguish services oriented to people in LEC as those directed towards physical and mental functions and activities that are indispensable for perfect development and even survival of people. Equivalents for SEC services are those directed towards improving such physical and mental aspects not indispensable for people development and survival. Services directed at things with LEC represent the development and/or improvement of those basic circumstances that allow the customer to keep or increase his/her economic or social status. Same services for SEC fulfill wishes that improve some aspects of perceptive nature for the individual in order to increase his/her life quality from the psychological point of view.

Deane et al. [23] have demonstrated that variables reflecting the interdependency of manufacturing/service and marketing strategies are the best predictor of firm success. Other researches, like Heskett et al. [34], Lovelock [35], Bowen et al. [36], or Chase and Hayes [37] have also demonstrated this asseveration. Skinner [38] recommended that the corporate strategy, that reflects the corporate marketing plan, establish the patterns that lead to the different focused service companies. Roth and Van der Velde share this point of view, when they suggest that a service strategy must address how operations will support and mesh with the competitive marketing thrusts of a business [15]. Unluckily, there is a scarcity of literature explaining how managers in service organisations systematically differentiate their businesses and how these advantages are deployed. Accordingly, it is necessary to develop a framework that explains how service firms should organise its activities so that marketing customised offerings are matched by the service operations system capabilities. We consider that the essential variables to analyse are those relating to the different processes and infrastructure used to support the LEC and SEC market segments.

Once we have set the LEC-SEC model, the next challenge is to identify those critical operations issues to implement either customer orientation. According to this idea, Berry et al. [39] propose that the key variables that need to be identified are process technology factors, volume factors, and infrastructure. As regards the important variables coming from the marketing side, Berry et al. propose market factors defining buyer behaviour, and time factors. Drawing from these ideas, we distinguish four Customisation Dimensions that condition the success of LEC and SEC initiatives. We propose these dimensions to be Time, Space, Scale and Scope. 
The Time Dimension refers to the ability of the service firm to 'produce' service just at the time the customer requires it. In the past, customers were willing to wait for their specialised needs, but now customers are seeking out vendors that can develop, produce, and deliver near-customised products in record time. This trend has placed unique demands on organisations, and they must respond to the challenge or risk losing their market share in the important custom-product market. Such a new trend has been described by McCutcheon et al. [28] as the 'customisation-responsiveness squeeze', and it is characterised by the need to deliver differentiated products in considerably less time than it takes to make them. This ability implies the existence of an optimal service demand management. Service firms must be able to increase its service capacity at peak demand times. Information Technologies (IT) help service firms to improve Customisation Time Dimension (CTD). An example of high incidence in CTD is a 24 hours Customer Information System via Telephone in which customer gets on line all the information required.

The Space Dimension refers to the ability of the service firm to 'produce' service just at the place the customer requires it. This implies an optimal management of the delivery system across the geographic area covered by the firm. The firm must be able to reach every spot of its potential service area by means of a well-designed logistics system. An example of high incidence in Customisation Space Dimension (CSD) is any fast pizza deliver service that compromises to deliver pizza anywhere inside its covered area.

The Scale Dimension refers to the capability of the service firm to deliver as much service as the customers require. This implies that the service firm needs to have a very flexible delivery system, meaning that the firm has to be able to increase the volume of services delivered, whenever required by the customers, without further complications or queue times for them. An example of the Customisation Scale Dimension (CScaD) are Medical Services, since they are given to patients as many times as their health conditions demand it.

The Scope Dimension refers to the capability of the service firm to adapt its services characteristics to those directly perceived by the customers as the essential features that the service has to have. They may either be part of the Core Service, or other added services that incorporate more value to the final service. This means that the service firm needs a flexible delivery system in the sense of being able to modify service or add new features to it in order to personalise it for the customer. Some examples of Customisation Scope Dimension (CScoD) are the possibility of choosing pizza ingredients, the use of specific medical instruments in Health service, or the added feature of changing decoration in a hotel room.

Table 1 shows how the Customisation Dimensions vary for LEC and SEC. In LEC service, professionals analyse customer needs, although it does not necessarily imply that customers may have made them explicit.

Chase and Tansik (1980) argued that since the customers are a source of uncertainty, the less they have to do with the service system, makes it easier to operate efficiently. In this context, decoupling means reducing the physical presence of customers in the internal organisation without necessarily limiting the exchange of information between customers and the service organisation. Initially, the customer fixes the Time and Space Dimensions. However, after the diagnosis, the company will keep the reins of the required service encounters. In a sense, we may assume that a LEC scenario is very much related to a PULL manufacturing system. 


\begin{tabular}{lll}
\hline & \multicolumn{2}{c}{ Customisation Dimensions } \\
\cline { 2 - 3 } Customisation Components & \multicolumn{1}{c}{ LEC } & \multicolumn{1}{c}{ SEC } \\
\hline Time (When?) & Anytime customer needs service & When customer wants service \\
Space (Where?) & $\begin{array}{l}\text { Any location wherein customer } \\
\text { needs service }\end{array}$ & $\begin{array}{l}\text { Where customer wants } \\
\text { service }\end{array}$ \\
Qualitative (How?) & As the professional decides & $\begin{array}{l}\text { As customer wants service } \\
\text { Quantitative (How much?) }\end{array}$ \\
& As much as professional decides & $\begin{array}{l}\text { As much as customer wants } \\
\text { service }\end{array}$ \\
\hline
\end{tabular}

The four dimensions of SEC are built up as a process of answering customer wishes. It might appear that the customer fixes how the firm has to organise its service operations system in order to fulfill his/her needs. In a way, the company will have to identify what the customer wishes ex-ante, so that all the resources will be prepared to deliver the service on a timely basis. This means that the company is in charge of the service delivery system as a whole, and that the market analysis will provide the required data for delivering the 'wishes' to the customer. According to this sequence, we may assume that SEC approaches are very similar to the PUSH manufacturing environments. Table 2 shows different degrees of Customisation dimensions for different service industries. Each service industry has been graded in a Likert Scale from 1 to 5 depending on degrec of Customisation ( 1 = Very Low, 5 = Very High) for each Customisation Dimension.

Table 2 Customisation components and service industries

\begin{tabular}{|c|c|c|c|c|c|c|}
\hline $\begin{array}{l}\text { Service } \\
\text { Industries/ } \\
\text { Customisation } \\
\text { Components }\end{array}$ & Airlines & Hospitals & $\begin{array}{l}\text { Professional } \\
\text { Senices }\end{array}$ & $\begin{array}{c}\text { Repair } \\
\text { Services }\end{array}$ & $\begin{array}{l}\text { Hotels and } \\
\text { Restaurants }\end{array}$ & $\begin{array}{c}\text { Information } \\
\text { Senvices }\end{array}$ \\
\hline Time & $\begin{array}{l}\text { At } \\
\text { Scheduled } \\
\text { Times (3) }\end{array}$ & $\begin{array}{l}\text { When } \\
\text { required (5) }\end{array}$ & $\begin{array}{l}\text { When } \\
\text { necessary } \\
(5)\end{array}$ & $\begin{array}{l}\text { Queues } \\
\text { problems } \\
\text { (3) }\end{array}$ & $\begin{array}{l}\text { Scheduled } \\
\text { except } 24 \\
\text { hours } \\
\text { service (4) }\end{array}$ & Online (5) \\
\hline Space & $\begin{array}{l}\text { At Airport } \\
\text { (1) }\end{array}$ & $\begin{array}{l}\text { Ambulances, } \\
\text { Doctors } \\
\text { moves to } \\
\text { patient } \\
\text { location (5) }\end{array}$ & $\begin{array}{l}\text { Office, } \\
\text { sometimes at } \\
\text { customer } \\
\text { location (3) }\end{array}$ & $\begin{array}{l}\text { At Repair } \\
\text { service } \\
\text { location (2) }\end{array}$ & $\begin{array}{l}\text { At service } \\
\text { location } \\
\text { except food } \\
\text { delivery } \\
(1 / 5)\end{array}$ & $\begin{array}{l}\text { Portable } \\
\text { Computers, } \\
\text { Lap Tops } \\
\text { (5) }\end{array}$ \\
\hline Quantitative & $\begin{array}{l}\text { Limited } \\
\text { food and } \\
\text { press } \\
\text { resources } \\
\text { (3) }\end{array}$ & $\begin{array}{l}\text { What patient } \\
\text { needs (5) }\end{array}$ & $\begin{array}{l}\text { As } \\
\text { professional } \\
\text { decides (4) }\end{array}$ & $\begin{array}{l}\text { As } \\
\text { professional } \\
\text { decides (4) }\end{array}$ & $\begin{array}{l}\text { As much as } \\
\text { customer } \\
\text { wants (3) }\end{array}$ & $\begin{array}{l}\text { What } \\
\text { customer } \\
\text { wants (5) }\end{array}$ \\
\hline Qualitative & $\begin{array}{l}\text { Ist and 2nd } \\
\text { class. Short } \\
\text { food menu } \\
\text { (2) }\end{array}$ & $\begin{array}{l}\text { Doctor } \\
\text { decides (5) }\end{array}$ & $\begin{array}{l}\text { As } \\
\text { professional } \\
\text { decides (4) }\end{array}$ & $\begin{array}{l}\text { As } \\
\text { professional } \\
\text { decides (4) }\end{array}$ & $\begin{array}{l}\text { Ingredients. } \\
\text { Customised } \\
\text { rooms (3) }\end{array}$ & $\begin{array}{l}\text { Languages, } \\
\text { speed (4) }\end{array}$ \\
\hline
\end{tabular}

Note: Degree of customisation ( $1=$ Very Low, $5=$ Very High) 
The customisation concept can be unfolded in different approaches and dimensions. The framework described in this paper can help service firms to identify their position in the LEC-SEC continuum. It also helps managers to identify those elements linked to the operations management domain, which can be modified in order to reposition the firms according to the Corporate Marketing Plan. Approaches (LEC and SEC) and dimensions (Time, Space, Scale and Scope) are perfectly combinable, since the customisation approaches clarify which kind of dimensions are more likely to be stressed depending on the specific service industry. The dimensions help service operations managers to address how operations will support and mesh with the competitive marketing thrusts of a business (as explained by Roth and Van der Velde [15]).

Future studies will have to identify how these Dimensions guide the design of the process of the Service Operations Strategy and how this process is implemented according to the LEC-SEC approach that every firm adopts. A complementary research stream point towards analysis of those kinds of services framed either in LEC or in SEC. Furthermore, researchers and professionals would be interested in determining the extent to which some service industries would be able to shift from one type of customisation to another or to a combination of both.

Also, the discussion of methods and models available for product development indicates the inadequacy of some models to support certain aspects of service development. For instance, when a service company plans to expand, reproducibility of the service concept becomes a fundamental attribute in creating a company identity, reducing costs and ensuring quality. It would be desirable to develop models that address in greater depth the connection between tangible design variables and intangible ones such as customer satisfaction and customer retention, among other variables. It would also be desirable to develop appropriate metrics that enable the translation of intangible attributes into specifications that can be used for service design.

A study of alternative representations of service systems is a topic that requires further research. It may help designers understand, among other issues, how design decisions freeze parts of the final design and drive the search for solutions in the development effort. So, future studies should strive to include more objective data, particularly financial measures of performance combined with qualitative data in order to know how flexible service companies are and how it is related to the customisation concept.

\section{Acknowledgements}

This research was funded by the CICYT projects DGICYT PB94-0372, DGES PB970089, and SEC2001-1578-C02-01. We are also grateful for support provided by the Faculty of Business of the Arizona State University during Spring 1997, Universidad Complutense de Madrid during the period 1997-1999 and the Real Colegio Complutense at Harvard University (1999). The authors have benefited from the many constructive comments made by Alvaro Cuervo, José Ignacio López, Luis Carretero, Beatriz Minguela (Complutense University), Mariano Nieto (University of León), Javier Llorens, and Luis M. Molina (University of Granada) in Spain as well as anonymous referees. Earlier 
versions of this paper were presented at the 1998 POMS Meeting "The History of Thought in Operations Management' (Santa Fe, New Mexico, USA; March 1998), and 1998 Euroma Conference 'Operations Management: Future Issues and Competitive responses'. (Dublin, May 1998), and the 1998 POMS International Meeting Conference: 'Competitiviness and Wealth Creation. The Role of Production and Operations Management'. (Capetown, South Africa, June.)

\section{References}

I Fornell, C. (1992) 'A national customer satisfaction barometer: the Swedish experience', Joumal of Marketing, Vol. 56, pp.6-21.

2 Easton, G.S. and Jarrel, S.L. (1998) 'The effects of total quality management on corporate performance: an empirical investigation', Jounal of Business, Vol. 71, No. 2, pp.253-307.

3 Lewis, R.C. and Klein, D.M. (1984) 'Taking off on service intangibles: theoretical and practical implications for marketing service', Ilorkshop on Research in Senvice Businesses, Institut d'Administration des Entreprises, Aix-en-Provence.

4 Parasuraman, A., Zeithaml, V.A. and Berry, L.L. (1985) 'A conceptual model of service quality and its implications for future research', Joumal of Marketing, Vol. 45, pp.41-50.

5 Anderson, E.W. and Sullivan, M.W. (1993) 'The antecedents and consequences of customer satisfaction for firms', Marketing Science, Vol. 12, No. 2, pp.125-143.

6 Iacobucci, D., Grayson, K. and Ostrom, A. (1994) 'Customer satisfaction fables', Sloan Management Review, Summer, pp.93-96.

7 Collier, D.A. and Meyer, S.M. (1998) 'A service positioning matrix', International Joumal of Operations and Production Management, Vol. 18, No. 12, pp.1223-1244.

8 Silvestro, R., Fitzgerald, L., Johnston, R. and Voss, C. (1992) 'Towards a classification of service processes', International Joturnal of Service Industry Management, Vol. 3, No. 3, pp.62-75.

9 Kellog, D.L. and Nie, W. (1995) 'A framework for strategic service management', Journal of Operations Management, Vol. 13, pp.323-337.

10 Fitzsimmons, J.A. and Fitzsimmons, M.J. (1994) Senice Management for Competitive Adrantage, McGraw Hill Inc.

11 Fitzsimmons, J.A. and Fitzsimmons, M.J. (1998) Service Management: Operations Strategy' and Information Techologies, McGraw Hill, Inc.

12 Lovelock, C.H. (1991) Service Marketing, 2nd ed., Prentice Hall, Englewood Cliffs, NJ.

13 Schmenner, R.W. (1990) Production/Operations Management, 4th ed., Macmillan, New York, NY.

14 Tinnila, M. and Vepsalainen, A.P.J. (1995) 'A model for strategic repositioning of service processes', International Joumal of Service Industry Management, Vol. 6, No. 4, pp.57-80.

15 Roth, A.V. and Van der Velde, M. (1991) 'Operations as marketing: a competitive service strategy', Joumal of Operations Mantagement, Vol. 10, No. 3, pp.303-327.

16 Ivancevich, J.M., Lorenzi, P., Skinner, S.J. and Crosby, P.B. (1996) 'Management', Quality' and Competitiveness, Irwin.

17 Armistead, C. (1992) 'Introduction to service operations', in Voss, C., Amistead, C., Johnston, B. and Morris, B. (Eds.): Operations Management in Senvice Industries and the Public Sector, John Wiley \& Sons.

18 Vandermerwe, S. (1992) 'The power is in the service because the value is in the result', in Lovelock, C.H. (Ed.), Managing Services, 2nd ed., Prentice Hall, Englewood Cliffs, NJ, pp. $298-309$. 
19 Griffin, A. and Hauser, J.R. (1993) 'Voice of the customer', Marketing Science, Vol. 12, pp.l27.

20 O'Farell, P.N., Hitchens, D.M. and Moffat, L.A.R. (1993) 'The competitive advantage of business service firms: a matched pair analysis of the relationship between generic strategy and performance', The Service Industry Journal, Vol. 13, No. 1, pp.40-64.

21 Goshal, S. (1987) 'Global strategy: an organizing framework', Strategic Management Joumal, Vol. 8, pp.425-440.

22 Kim, W.C., Hwang, P. and Burguers, W.P. (1989) 'Global diversification strategy and corporate profit performance', Strategic Management Journal, Vol. 10, pp.45-57.

23 Deane, R.H., McDougall, P.P. and Gargeya, V.B. (1991) 'Manufacturing and marketing interdependence in the new venture firm: an empirical study', Journal of Operations Management, Vol. 10, No. 3, pp.329-362.

24 Johnston, R. and Morris, B. (1985) 'Monitoring and control in service operations', International Journal of Operations and Production Management, Vol. 5, No. 4, pp.35-44.

25 Bitran, G. and Pedrosa, L. (1998) 'A structured product development perspective for service operations', European Management Journal, Vol. 16, No. 2, pp.169-189.

26 Bateson, J. (1985) 'Perceived control and the service encounter', in Czepiel, J.A., Solomon, M.R. and Surprenat, C.F. (Eds.): The Service Encounter, Lexington Books, Lexington, Mass., pp.76-83.

27 Hayes, R.H. and Upton, D.M. (1998) 'Operations-based strategy', California Management Review, Vol. 40, No. 4, pp.8-25.

28 McCutcheon, D.M., Raturi, A. and Meredith, J. (1994) The Customization-Responsiveness Squeeze, Winter, pp.89-99.

29 Voss, C.A., Armistead, C., Johnston, B. and Morris, B. (1992) Operations Management in Service Industries and the Public Sector, John Wiley \& Sons.

30 Maister, D. and Lovelock, C.H. (1982) 'Managing facilitator services', Sloan Management Review, Summer, pp.19-31.

31 Chase, R.B. (1981) 'Customer contact approach to service: theoretical bases and practical extensions', Operations Research, Vol. 29, No. 4, pp.698-706.

32 Schmenner, R.W. (1986) 'How can service businesses survive and prosper?' Sloan Management Review, Vol. 27, No. 5, p.25.

33 Lovelock, C.H. (1983) 'Classifying services to gain strategic marketing insights', Journal of Marketing, Vol. 47, pp.9-20.

34 Heskett, J.L., Sasser Jr., W.E. and Hart, C.W.L. (1990) Service Breakthroutghs: Changing the Rules of the Game, New York: The Free Press.

35 Lovelock, C.H. (1988) Managing Services (Marketing, Operations and Htiman Resources), Prentice Hall International Editions, Londres.

36 Bowen, D.E., Chase, R.B. and Cummings, T.G. (Eds.) (1990) Service Management Effectiveness, Jossey Bass, San Francisco, CA.

37 Chase, R.B. and Hayes, R.H. (1991) 'Beefing up operations in service firms', Sloan Management Review, Fall, pp.15-26.

38 Skinner, W. (1974) 'The focused factory', Harvard Business Review, Vol. 52, No. 3, pp.113121.

39 Berry, W.L., Bozarth, C.C., Hill, T. and Klompmaker, J.E. (1991) 'Factory focus: segmenting markets from an operations perspective', Journal of Operations Management, Vol. 10, No. 3, pp.363-387. 


\section{Bibliography}

Chase, R.B. and Erikson, W. (1988) 'The service factory', Academy of Management Executive, Vol. 2, pp.191-196.

Flynn, B.B., Schroeder, R.G. and Sakakibara, S. (1995) 'The impact of quality management practices on performance and competitive advantage', Decision Sciences, Vol. 26, No. 5, pp.659-689.

Griffin, A., Gleason, G., Preiss, R. and Shevenaugh, D. (1995) 'Best practice for customer satisfaction in manufacturing firms', Sloan Management Review', pp.87-98.

Karmarkar, U.S. and Pitbladdo, R. (1995) 'Service markets and competitions', Journal of Operations Management, Vol. 12, pp.397-411.

Parasuraman, A., Zeithaml, V.A. and Berry, L.L. (1994) 'Reassessment of expectations as a comparison standard in measuring service quality: implications for further research', Journal of Marketing, Vol. 58, pp.111-124.

Quinn, J.B. (1992) Intelligent Enterprise, The Free Press, New York.

Roth, A.V. and Jackson, W.E. (1995) 'Strategic determinants of service quality and performance: evidence from the banking industry', Management Science, Vol. 41, No. 11, pp.1720-1733.

Sampson, S.E. (1996) 'Ramifications of monitoring service quality through passively solicited customer feedback', Decision Sciences, Vol. 27, No. 4, pp.601-621.

Sasser, W.E., Olsen, R.P. and Wyckoff, D.D. (1978) Management of Service Operations, Ed. Allyn and Bacon, Inc., Boston.

Sulek, J., Linnd, M. and Marucheck, A. (1995) 'The impact of a customer service intervention and facility design on firm performance', Management Science, Vol. 41, pp.1763-1773.

Turpin, D.V. (1995) 'Japanese approaches to customer satisfaction: some best practices', Long Range Planning, Vol. 28, No. 3, pp.84-90.

Wemmerlov, U. (1990) 'A taxonomy for service process and its implications for system design', International Journal of Service Industry Management, Vol. 1, No. 3. 